\title{
Long-term clinical and ultrasonographic evaluation of thrombophilic patients with deep venous thrombosis
}

\author{
Avaliação clínica e ultrassonográfica tardia de pacientes \\ com trombose venosa profunda, portadores de trombofilia \\ Viviane Alessandra Capelluppi Tófano 1,2, Francisco Humberto Abreu Maffei³, Hamilton Almeida Rollo3, \\ Marcone Lima Sobreira ${ }^{3}$, Carlos Roberto Padovani ${ }^{4}$, Isolete Tomazini Aparecida Santos ${ }^{5}$
}

\begin{abstract}
Objective: The purpose of this study was to evaluate the long term clinical and ultrasonographic outcomes of thrombophilic patients with deep venous thrombosis (DVT). Method: Cohort study, retrospective case-control with cross-sectional analysis. Thirty-nine thrombophilic patients and 25 non-thrombophilic patients were assessed $76.3 \pm 45.8$ months after diagnosis. Demographic and family data were collected, as well as data from clinical and therapeutic progress, and physical and ultrasound examinations of the limbs were performed. Groups were matched for age and gender and the variables studied were compared across groups. Results: Deep venous thrombosis was more frequent in women. The most common thrombophilias were antiphospholipid syndrome and factor $V$ Leiden mutation. There was no difference between groups in terms of the number of pregnancies or miscarriages and the majority of women did not become pregnant after DVT. Non-spontaneous DVT prevailed. Proximal DVT and DVT of the left lower limb were more frequent, and the main risk factor was use of oral contraceptives. All patients were treated with anticoagulation. There was a higher frequency of pulmonary embolism in non-thrombophilic patients. Most patients considered themselves to have a "normal life" after DVT and reported wearing elastic stockings over at least 2 years. Seventy-one percent of patients had CEAP $\geq 3$, with no difference between groups. Deep venous reflux was more frequent in thrombophilic patients. Conclusion: There were no significant differences between groups with respect to most of the variables studied, except for a higher frequency of pulmonary embolism in non-thrombophilic patients and greater frequency of deep venous reflux in thrombophilic patients.
\end{abstract}

Keywords: deep vein thrombosis; thrombophilia; postthrombotic syndrome; pulmonary embolism; duplex scan.

\begin{abstract}
Resumo
Objetivo: A proposta deste estudo foi realizar a avaliação clínica e ultrassonográfica em longo prazo de pacientes com diagnóstico de trombose venosa profunda (TVP), portadores de trombofilia. Método: estudo coorte, caso-controle retrospectivo com análise transversal. Foram estudados 39 pacientes portadores de trombofilia (PT) e 25 pacientes não portadores de trombofilia (PNT), dentro de um intervalo de tempo de 76,3 \pm 45,8 meses, após o diagnóstico de TVP. Foram coletados dados demográficos e antecedentes familiares, assim como dados referentes à evolução clínica e terapêutica, tendo sido realizado também exame físico e ultrassonográfico dos membros envolvidos. Os grupos foram pareados quanto à idade e ao sexo, e as variáveis estudadas foram comparadas entre os grupos. Resultados: TVP foi mais frequente em mulheres. As trombofilias mais comumente encontradas foram a síndrome antifosfolípide e a mutação do fator $\vee$ Leiden. Não houve diferença entre os grupos considerando-se o número de gestações e abortamentos, e a maioria das mulheres não engravidou após o episódio de TVP. A TVP não espontânea prevaleceu. A TVP proximal e em membro inferior esquerdo foi a mais frequente, e o principal fator de risco foi o uso de anticoncepcional oral. Todos os pacientes foram tratados com anticoagulação. Houve predomínio de embolia pulmonar (EP) nos pacientes não portadores de trombofilia. A maioria dos pacientes considerava ter uma 'vida normal' após o episódio de TVP e estes relataram o uso de meia elástica por, pelo menos, dois anos. Dos pacientes, 71\% apresentaram CEAP $\geq 3$, sem diferença quando foi comparado entre os grupos estudados. O refluxo venoso profundo foi mais frequentemente observado no grupo de pacientes portadores de trombofilia. Conclusão: Não houve diferenças significativas entre os grupos com relação à maioria das variáveis estudadas, com exceção de uma prevalência da EP no grupo não portador de trombofilia e maior presença de refluxo venoso profundo no grupo portador de trombofilia.
\end{abstract}

Palavras-chave: trombose venosa profunda; trombofilia; síndrome pós-trombótica; embolia pulmonar; mapeamento dúplex.

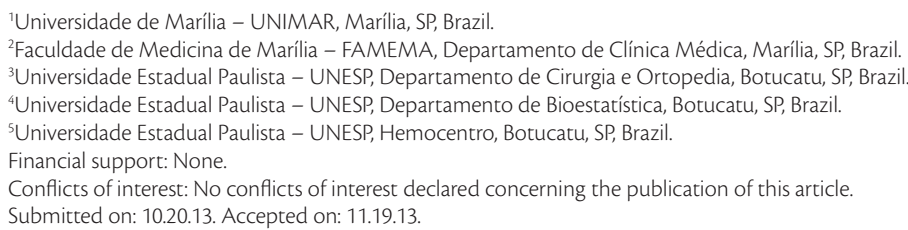




\section{INTRODUCTION}

Deep vein thrombosis (DVT) has both clinical and epidemiological importance because it is a high incidence disease, with an estimated 60 cases/100,000 inhabitants/year in Brazil, ${ }^{1}$ leading to more than 600,000 hospital admissions per year. ${ }^{2}$ Pulmonary embolism (PE) is the most feared acute complication and is the third leading cause of hospital deaths, killing 50,000 to 100,000 patients per year in the U.S. ${ }^{3}$ Risk factors for DVT include: immobilization, trauma, surgery, old age, obesity, pregnancy, puerperium, cancer, estrogen use and genetic and acquired thrombophilias. ${ }^{4-10}$

Although the genetic thrombophilias, natural anticoagulant, antithrombin (AT), protein S (PS) and protein $\mathrm{C}$ (PC) deficiencies, are rare in the general population, with an incidence of $0.3-0.5 \%$, 2,9 they are responsible for up to $15 \%$ of venous thromboembolism (VTE) cases. The incidence of spontaneous thromboembolism in patients with these deficiencies is estimated at $0.4 \%$ per year, while the rate for secondary thromboembolisms associated with other triggering risk factors increases to between $8.1 \%$ and $10 \%{ }^{6,10,11}$ The most common of these is the factor V R306Q mutation (FV Leiden) which causes resistance to the action of $\mathrm{PC}$, appearing in 1 to $15 \%$ of the general population and in 10 to $50 \%$ of patients with VTE. ${ }^{12,13}$ The G20210A polymorphism of the prothrombin gene is associated with increased plasma prothrombin levels and is present in 1 to $3 \%$ of individuals in the general population and 6 to $18 \%$ of patients with VTE. ${ }^{14}$ While the methylenetetrahydrofolatereductase mutation (MTHFR) does not itself appear to be a risk factor for DVT, ${ }^{15}$ it may be associated with hyperhomocysteinemia. ${ }^{16}$ Antiphospholipid syndrome (APS) is an acquired thrombophilia, characterized by the occurrence of venous thrombosis and/or arterial thrombosis and/or recurrent miscarriages in the presence of laboratory evidence of antiphospholipid antibodies. ${ }^{17}$

Deep venous thrombosis can have acute or chronic complications and is a significant cause of morbidity and mortality. Pulmonary embolism is an acute complication that occurs in approximately $20 \%$ of DVT cases. ${ }^{18}$ It is potentially fatal, especially in cases of recurring VTE; in which $5 \%$ of patients run this risk. ${ }^{19}$ The post-thrombotic syndrome (PTS) is a chronic complication with a mortality rate of almost zero. However, it is important from an epidemiological point of view due to its high morbidity and the resulting socioeconomic costs. Recent studies report that $50 \%$ of patients with DVT develop PTS, which is classified as severe in $1 / 5$ of patients. ${ }^{20}$

There are some studies that have evaluated long term clinical outcomes in patients with DVT, relating them to the characteristics of the patients and to treatment. ${ }^{3,21} \mathrm{Few}$, however, have assessed the later evolution of patients with thrombophilia. Spiezia et al. ${ }^{22}$ recently evaluated thrombophilia as a specific risk factor for PTS, finding no difference between thrombophilic patients and nonthrombophilic patients in the development of this syndrome.

Taking into account the socioeconomic and healthcare characteristics of our population in a developing country, possibly different from patients in North America and Europe, we evaluated clinically and by ultrasound the long term evolution of thrombophilic patients with DVT confirmed by objective methods, treated at a University Hospital in a provincial city in the state of São Paulo, Brazil.

\section{PATIENTS AND METHODS}

We declare that this study was approved by the Research Ethics Committee at the Universidade Estadual Paulista (UNESP).

We also declare that all patients enrolled agreed to participate in the study and signed a Statement of Consent.

\section{Patients}

This was a retrospective, case-control, cohort study. A cross-sectional analysis was performed at the same time as an interview and a duplex scan were conducted. All procedures were undertaken at a single center, the University Hospital at the Botucatu School of Medicine, UNESP, in Botucatu, Sao Paulo, Brazil.

A total of 220 patients had been tested for genetic thrombophilia as part of a prior multicenter research project (BRATROS - BRAZILIAN THROMBOSIS STUDY) $)^{13,16}$ and had been followed-up at the hospital's Anticoagulation Clinic. The patients had been tested for the following thrombophilias: AT, PC and PS deficiencies, FV Leiden, the G20210A prothrombin gene mutation, the MTHFR C677T gene mutation in homozygosis and APS. We reviewed the medical records for these 220 patients and identified 37 patients with at least one genetic thrombophilia. Six of these patients were excluded because of cerebral vein thrombosis or death and one patient refused to participate in the study, leaving a sample of 30 patients. A further 14 patients who had DVT and a genetic and/or acquired thrombophilia, but 
had not participated in the BRATROS study were also enrolled. Finally, 14 patients with positive anticardiolipin antibody test results and two patients positive for lupus anticoagulant, with DVT of the limbs, identified among patients who had been tested for APS at the Hemostasis Laboratory from January 2001 to December 2003, were also recruited to the sample. Therefore, the study population comprised 60 patients with genetic and/or acquired thrombophilias who were treated for upper or lower limb DVT confirmed by duplex scanning, with or without PE.

Patients still in follow-up at the Anticoagulation Clinic were approached during routine consultations. For patients who were no longer in follow-up, contact attempts were made via telephone, letter and/or social services. Forty of the 60 patients were located and one refused to participate in the study, leaving a total of 39 patients.

We selected 25 patients from the BRATROS study who did not have genetic and/or acquired thrombophilias (control group - CG) and who could be matched for gender and age with 25 patients in the thrombophilia group (TG).

During consultation, a questionnaire was administered, physical examination of the limbs was performed and a duplex scan was scheduled.

\section{Variables analyzed}

The study protocol contained items that included data from a questionnaire/interview and data collected from medical records and charts, including demographics, profession, type of work, personal and obstetric history, family history, VTE history (spontaneous or not), time since diagnosis, associated thrombophilia, results of initial duplex scan, initial treatment and outpatient international normalized ratio (INR), rethrombosis, bleeding complications, PE, anticoagulant treatment time, signs and symptoms of PTS, quality of life and use of compression stockings (CS).

A venous-disease specific physical examination based on the CEAP classification was conducted. ${ }^{3}$

Duplex scanning was used to assess the superficial and deep venous systems, with analysis of vein patency and venous reflux (duration and velocity), as described by Lapropoulos, ${ }^{23}$ using a LOGIK 7 GE machine with a 4 to $7 \mathrm{MHz}$ multifrequency linear transducer.

\section{Laboratory tests}

Coagulation inhibitor deficiencies were assayed using commercial chromogenic substrate kits, in accordance with their manufacturer's instructions (Helena Laboratories, Inc. in Beaumont, TX, United States). Genotyping for genetic thrombophilias employed PCR and restriction protocols - digestion, as described elsewhere. ${ }^{12,14}$ The Sapporo Criteria ${ }^{24}$ were used for APS determination.

\section{Statistical analysis}

The data collected were coded as numbers and input to an Excel spreadsheet for statistical analysis. The programs used for statistical tests were as follows: MANAP, a program developed by the UNESP Department of Biostatistics, was used for the Goodman test and SAEG for Windows, a program developed by the Universidade Federal de Visçosa/ MG, was used for the Mann-Whitney test.

The Goodman test for contrasts between and within multinomial populations was used to identify associations between groups and clinical and ultrasonographic variables. ${ }^{25-27}$ Continuous variables were analyzed using the Mann-Whitney nonparametric test for independent groups. ${ }^{27}$ We used lowercase letters to indicate the results of comparisons between groups (control vs. thrombophilic), which was defined as the response category, and we used capital letters for the results of comparisons of response categories within groups, according to the following rules: a) two consecutive proportions with the same lower case letter did not differ in their respective groups in the category of the response in question; b) two consecutive proportions with at least one capital letter do not differ as to their respective response categories within the group in question; and c) the earlier the position in the alphabet, the lower the percentage, so that: $\mathrm{a}<\mathrm{b}<\mathrm{c}$... and $\mathrm{A}<\mathrm{B}<\mathrm{C}$...

The Compliance Test - chi-square, was applied to the thrombophilic group variables shown in Table $1 .^{28}$

$P$ values of $<0.05$ value were considered statistically significant.

\section{RESULTS}

\section{Descriptive and statistical analysis of the thrombophilic patients $(n=39)$}

The mean age of the thrombophilic group was $37.2( \pm 13.7)$ and median age was $37.0(10.0 ; 68.0)$.

Mean follow-up time (in months) was $76.3( \pm 45.9)$ and median follow-up was $60.0(12.0 ; 216.0)$.

Compression stockings were being worn by $35.1 \%$ of thrombophilic patients after their DVT episodes and $22.3 \%$ of those who reported not wearing them 
at the time of the interview, reported having worn them for at least 2 years.

Deep venous thrombosis recurred in $41.1 \%$ of the thrombophilic patients, $23 \%$ in the same limb and $15.5 \%$ in the contralateral limb. Four patients had rethrombosis while on anticoagulation and with INRs between 2.0 and 3.0. Thrombophlebitis was reported by $2.6 \%$ of patients.

The other demographic and clinical characteristics of the thrombophilic patients are summarized in Table 1.
The most common thrombophilias were APS, followed by heterozygous FV Leiden (Table 2).

Table 3 lists the distribution of thrombophilic patients according to the CEAP classification.

\section{Comparative analysis (thrombophilic group vs. control group)}

Twenty-five thrombophilic patients (Thrombophilic Group, TG) and 25 control patients (Control Group, CG) were matched for gender and age. There was no statistical difference between the

Table 1. Demographic and clinical characteristics of the thrombophilic patients.

\begin{tabular}{|c|c|c|c|}
\hline \multirow{2}{*}{$\frac{\text { Characteristics }}{\text { Gender }}$} & \multicolumn{2}{|c|}{ Percentage $(n=39)$} & \multirow{2}{*}{$\frac{p \text { value }}{p<0.01}$} \\
\hline & Male: 25 & Female: 75 & \\
\hline Ethnicity & Caucasians: 97.4 & African descendants: 2.6 & $\mathrm{p}<0.001$ \\
\hline Origin & Urban: 94.8 & Rural: 5.2 & $\mathrm{p}<0.001$ \\
\hline \# of pregnancies (before the DVT) & Up to 2: 76.6 & $>2: 23.4$ ( $n=30$ women $)$ & $\mathrm{p}<0.05$ \\
\hline \# of pregnancies (after the DVT) & Up to $2: 96.6$ & $>2: 3.4$ (n=30 women) & $\mathrm{p}<0.001$ \\
\hline \# of miscarriages (after the DVT) & None: 86.6 & 1: 13.4 & $\mathrm{p}<0.001$ \\
\hline Relatives with DVT & No: 82 & Yes: 18 & $\mathrm{p}<0.001$ \\
\hline Relatives with PE & No: 100 & No: 100 & $\mathrm{p}<0.001$ \\
\hline Relatives with arterial thrombosis & No: 84.6 & Yes: 15.4 & $\mathrm{p}<0.001$ \\
\hline Spontaneous DVT & No: 61.5 & Yes: 38.5 & $\mathrm{p}<0.05$ \\
\hline Affected limb & Upper: 5.1 & Lower: 94.9 & $\mathrm{p}<0.001$ \\
\hline DVT Level & Distal: 17.9 & Proximal: 82.1 & $\mathrm{p}<0.001$ \\
\hline Use of heparin & Yes: 100 & Yes: 100 & $\mathrm{p}<0.001$ \\
\hline Type of heparin & HBPM: 12.8 & HNF: 87.2 & $\mathrm{p}<0.001$ \\
\hline AVK (Warfarin) & Yes: 100 & Yes: 100 & $\mathrm{p}<0.001$ \\
\hline Hemorrhagic complications & No: $71.4 \%$ & Yes: 28.6 & $\mathrm{p}<0.05$ \\
\hline Perennial anticoagulation & No: $36 \%$ & Yes: 64 & $\mathrm{p}<0.05$ \\
\hline Pulmonary embolism & No: 92.3 & Yes: 7.7 & $\mathrm{p}<0.001$ \\
\hline Pain in the affected limb & No: $38.4 \%$ & Yes: 61.6 & $\mathrm{p}<0.05$ \\
\hline Report of edema & No: 23 & Yes: 77 & $\mathrm{p}<0.01$ \\
\hline Report of change in skin coloring & No: 58.9 & Yes: 41.1 & $\mathrm{p}<0.05$ \\
\hline Report of open ulcer & No: 89.7 & Yes: 10.3 & $\mathrm{p}<0.001$ \\
\hline Report of erysipelas & No: 92.3 & Yes: 7.7 & $\mathrm{p}<0.001$ \\
\hline Normal life post-DVT? & No: 25.6 & Yes: 74.4 & $\mathrm{p}<0.01$ \\
\hline Working normally? & No: 24 & Yes: 76 & $p<0.01$ \\
\hline Retired because of DVT? & No: 82.1 & Yes: $17.9 \%$ & $\mathrm{p}<0.01$ \\
\hline Has physical limitations? & No: $66.6 \%$ & Yes: 33.4 & $\mathrm{p}<0.05$ \\
\hline $\mathrm{BMI}$ & Normal: 61.5 & Overweight or obese: 35.9 & $\mathrm{p}<0.05$ \\
\hline
\end{tabular}

Table 2. Distribution of patients according to type of thrombophilia.

\begin{tabular}{cccccccccc}
\hline \multicolumn{10}{c}{ THROMBOPHILIAS } \\
\hline APS 1 & APS 2 & FVL het. & FVL ho & Prot het & Prot ho & PC & MTHFR homo & Multiple thrombophilias & Total \\
\hline 12 & 6 & 10 & 1 & 2 & 1 & 1 & 4 & 2 & 39 \\
$(30.76 \%)$ & $(15.4 \%)$ & $(25.6 \%)$ & $(2.6 \%)$ & $(5.1 \%)$ & $(2.6 \%)$ & $(2.6 \%)$ & $(10.5 \%)$ & $(5.1 \%)$ & $(100 \%)$ \\
\hline
\end{tabular}

APS 1: primary antiphospholipid syndrome. APS 2: secondary antiphospholipid syndrome. FVL het: heterozygous factor $V$ Leiden. FVL ho: homozygous factor $V$ Leiden. Prot het: heterozygous prothrombin. Prot ho: homozygous prothrombin. PC: protein C deficiency. MTHFR homo: homozygous methylenetetrahydrofolate reductase. Multiple thrombophilias $=$ FVL het + MTHFR homo. 
groups in terms of any of the following variables: ethnicity, urban or rural origin, profession, number of pregnancies after DVT or number miscarriages after DVT. Before DVT, women in the TG had a greater number of miscarriages than women in the CG. There was no family history of thrombosis in either group. Non-spontaneous DVT was more frequent than spontaneous DVT in both groups, as were its associated risk factors, including use of oral contraceptives. Lower limb, left limb and proximal DVT predominated in both groups. Pulmonary embolism was more frequent in the control group. Hemorrhagic complications related to use of warfarin were mostly mild in both groups. Most patients reported having a "normal life" after the thrombotic episode. Most patients stated that they were not wearing CS when interviewed.

Analyses of the frequency of PTS, according to CEAP grades, showed a tendency towards CEAP $\geq 3$ in both groups (Tables 4 and 5). No difference between groups was observed in patients with $C E A P \geq 3$ for proximal DVT, ipsilateral rethrombosis, BMI or wearing CS for at least 2 years $(p>0.05)$. Pathological venous reflux seen on duplex scan was more frequent in the thrombophilic group than in the control group $(\mathrm{p}<0.05)$.

Duplex scans of the deep venous systems of the majority of patients in both groups showed signs of venous recanalization (Table 6). There was no statistical difference in reflux speed between thrombophilic and control groups, but there was a predominance of speeds greater than or equal to 30 $\mathrm{cm} / \mathrm{s}$ in both groups. The control group exhibited a deep venous reflux time greater than 1 second, but there was no statistical difference between the groups (Table 7).

\section{DISCUSSION}

The most frequent thrombophilia found in the patients studied here was primary APS, followed by heterozygous FV Leiden. The frequency of APS in our patients was higher than is reported in the literature (4-14\%). ${ }^{17,29,30} \mathrm{We}$ have no explanation for this high frequency, which seems to be real, since we used the Sapporo Criteria to diagnose our cases $^{31}$ and antibodies remained high 60 days after the first assays. On the other hand, our results are similar to the literature in relation to FV Leiden, which is the most common genetic condition linked with DVT,

Table 3. Distribution of patients in the thrombophilic group according to the CEAP classification.

\begin{tabular}{ccccccccccc}
\hline & CEAP & CEAP & CEAP & CEAP & CEAP & CEAP & CEAP & CEAP & Total \\
\hline \multirow{2}{*}{ Patients } & 0 & 1 & 2 & 3 & $4 a$ & $4 b$ & 5 & 6 & \\
& 6 & 0 & 4 & 13 & 8 & 1 & 3 & 2 & 37 \\
& $(16.2 \%)$ & $(0 \%)$ & $(10.8 \%)$ & $(35.1 \%)$ & $(21.6 \%)$ & $(2.7 \%)$ & $(8.1 \%)$ & $(5.4 \%)$ & $(100 \%)$ \\
\hline
\end{tabular}

Table 4. Distribution of patients according to CEAP classification in both study groups. Analyses of PTS, considering the CEAP grades, showed a tendency to CEAP $\geq 3$ in both groups.

\begin{tabular}{|c|c|c|c|c|c|c|c|c|c|}
\hline \multicolumn{10}{|c|}{ CEAP } \\
\hline Group & 0 & 1 & 2 & 3 & $4 a$ & $4 \mathrm{~b}$ & 5 & 6 & Total \\
\hline Control & $\begin{array}{c}4 \\
(17.4 \%)\end{array}$ & 0 & $\begin{array}{c}3 \\
(13.0 \%)\end{array}$ & $\begin{array}{c}10 \\
(43.5 \%)\end{array}$ & $\begin{array}{c}5 \\
(21.7 \%)\end{array}$ & 0 & 0 & $\begin{array}{c}1 \\
(4.3 \%)\end{array}$ & 23 \\
\hline Thrombophilic & $\begin{array}{c}2 \\
(8.7 \%)\end{array}$ & 0 & $\begin{array}{c}3 \\
(13.0 \%)\end{array}$ & $\begin{array}{c}8 \\
(34.8 \%)\end{array}$ & $\begin{array}{c}6 \\
(26.1 \%)\end{array}$ & $\begin{array}{c}1 \\
(4.34 \%)\end{array}$ & $\begin{array}{c}3 \\
(13.0 \%)\end{array}$ & 0 & 23 \\
\hline
\end{tabular}

Table 5. Distribution of other variables in patients with CEAP $\geq 3$, for both groups

\begin{tabular}{cccccc}
\hline CEAP $\geq 3$ & $\begin{array}{c}\text { Proximal DVT } \\
(\mathrm{Fe} / \mathrm{IF})\end{array}$ & $\begin{array}{c}\text { Ipsilateral } \\
\text { Rethrombosis }\end{array}$ & $\begin{array}{c}\mathrm{BMI} \\
\text { (overweight/obese) }\end{array}$ & $\begin{array}{c}\text { Elastic Stockings } \\
(>2 \text { years })\end{array}$ & $\begin{array}{c}\text { Reflux } \\
(\mathrm{t} / \mathrm{s})\end{array}$ \\
\hline $\begin{array}{c}\text { Control } \\
\text { (16 patients) }\end{array}$ & $7(43.8 \%)$ & $9(56.3 \%)$ & $10(62.5 \%)$ & $7(43.8 \%)$ & $7(43.8 \%)$ \\
$\begin{array}{c}\text { Thrombophilic } \\
(18 \text { patients })\end{array}$ & $9(50.0 \%)$ & $6(33.3 \%)$ & $10(55.6 \%)$ & $8(44.4 \%)$ & $14(77.8 \%)$ \\
p value* $^{*}$ & $\mathrm{p}>0.05$ & $\mathrm{p}>0.05$ & $\mathrm{p}>0.05$ & $\mathrm{p}>0.05$ & $\mathrm{P}<0.05$ \\
\hline
\end{tabular}


Table 6. Duplex scan findings for deep venous system patency, in both groups.

\begin{tabular}{cccc}
\hline Group & $\begin{array}{c}\text { Complete } \\
\text { Recanalization }\end{array}$ & $\begin{array}{c}\text { Partial } \\
\text { Recanalization }\end{array}$ & Total \\
\hline Control & $4(18.2) \mathrm{aA}$ & $18(81.8) \mathrm{aB}$ & 22 \\
Thrombophilic & $7(30.4) \mathrm{aA}$ & $16(69.6) \mathrm{aB}$ & 23 \\
\hline
\end{tabular}

Table 7. Distribution according to deep venous reflux time on duplex.

\begin{tabular}{cccc} 
Group & $0.5-1.0 \mathrm{~s}$ & $>1 \mathrm{~s}$ & Total \\
\hline Control & $2(20.00) \mathrm{aA}$ & $8(80.00) \mathrm{aB}$ & 10 \\
Thrombophilic & $8(40.00) \mathrm{aA}$ & $12(60.00) \mathrm{aB}$ & 20 \\
\hline
\end{tabular}

increasing the risk of thrombotic events by five to ten times in heterozygotic carriers and more than ten times in homozygotic patients, ${ }^{6,11}$ especially in association with other risk factors such as advanced age (over 65) or oral contraceptive use, ${ }^{7,9,15,29}$ which was the second most common risk factor in our patient sample.

On the basis that previous studies have linked pregnancy complications, including miscarriages, with thrombophilias, ${ }^{32-35}$ mainly APS, we examined the number of pregnancies and miscarriages before and after each DVT episode, comparing thrombophilic with non-thrombophilic patients. Before DVTs, female patients in the thrombophilic group had more miscarriages than those in the control group and a greater number of gestational complications, as reported in the literature. ${ }^{17,36}$ After DVT, 16 out of 19 female patients in both groups did not get pregnant, which can possibly be attributed to the medical advice they received regarding the risk of rethrombosis during pregnancy.

The relatives of the DVT patients in this study did not have a higher incidence of arterial and/or venous thrombosis episodes, including PE. There is not yet consensus in the literature on the need for investigation of the relatives of patients with genetic thrombophilia; the results of studies conducted to date are contradictory. ${ }^{37}$

Deep venous thrombosis is considered a multifactorial disease. ${ }^{5}$ In recent years, knowledge about the etiology of VTE has advanced with the discovery of several factors that contribute to increased incidence of thrombosis, particularly coagulation abnormalities. These abnormalities are found in the general population and understanding the interactions between genetic and environmental risk factors may be the key to understand VTE. This is why we attempted to identify other factors present in all patients in the present study. Most patients in the TG $(61.5 \%)$ did not have spontaneous DVT. In these patients, the most common factors identified were use of oral contraceptives (22\%) followed by puerperium (13\%). The higher than normal frequency of these risk factors in this study may indicate bias, since the majority of patients were female, but it is also true that the greater number of women with thrombophilia and thrombosis could be due to these risk factors being common among women. There was no statistical difference between groups, resulting in a greater number of patients with non-spontaneous DVT also in the control group. An earlier cohort study that investigated additional risk factors related to the FV Leiden mutation found that $42 \%$ of symptomatic patients with an average age of 65 years had some additional risk factor, demonstrating once more that the interaction between genetic and/or acquired risk factors can indeed explain the occurrence of VTE..$^{38}$

With regard to DVT location, there was a higher prevalence of proximal DVT, with no difference between groups, in contrast to findings reported by Martinelli et al. ${ }^{39}$ where distal thrombosis was more frequent in patients with FV Leiden. Perhaps this is due to the fact that proximal thrombosis, being more symptomatic, is more likely to provoke patients to seek medical care. In the present study, there were no significant differences between patients with thrombophilia and the CG in terms of which limb was affected or whether DVT was distal or proximal.

Pulmonary embolism was observed in $8 \%$ of the TG and in $16 \%$ of the CG and one possible explanation for this fact is that a greater number of thrombophilic patients than CG patients were on permanent anticoagulation. Martinelli et al. ${ }^{39}$ observed no difference in PE occurrence on the basis of DVT location and found that symptomatic PE was less frequent in patients with FV Leiden $(6 \%)$ than in patients with the prothrombin mutation $(21 \%)$ and than in non-thrombophilic patients (23\%).

The long-term complications of DVT, rethrombosis and PTS may be directly related to duration of anticoagulant treatment and other therapeutic practices and can interfere with patients' quality of life. The DVT recurrence frequency reported in the literature is $3 \%$ to $13 \%$ in the first year and $12 \%$ to $28 \%$ over five years. ${ }^{19}$ In our study, in which patients were re-examined 1 to 18 years after the first DVT episode (median five years), we observed a high rate of DVT recurrence: $36 \%$ and $32 \%$ in the TG and CG respectively. Four thrombophilic patients had rethrombosis while on 
anticoagulation and with adequate INRs (between 2.0 and 3.0). It is possible that if higher INR levels had been maintained in these patients, rethrombosis would have not occurred, although use of higher levels of anticoagulation is not part of the current recommendations in the International Consensus. ${ }^{21}$ It has been shown that recurrence of ipsilateral DVT is a strong predictor of PTS and that long periods of anticoagulation and wearing CS seems to prevent it. $^{40-43}$ In this study, there was a greater number of TG patients with ipsilateral rethrombosis among those who had CEAP $\geq 3$ than among thrombophilic patients with $\mathrm{CEAP}<3$, but the difference did not attain statistical significance. We did not observe any difference between thrombophilic and control groups in terms of complaints or CEAP-based physical examination findings, in contrast with reports that have shown lower PTS incidence in patients with genetic thrombophilia. ${ }^{43}$

Slightly more than half of the patients, both thrombophilic and non-thrombophilic, reported wearing CS for the minimum period of two years that is recommended for prevention of PTS, but the frequency of PTS observed in these patients was similar to that in the control group patients who did not wear CS. These results contrast with findings published by Prandoni et al. ${ }^{40}$ and Brandjes et al. ${ }^{41}$ who reported a 50\% reduction in PTS frequency among patients who wore CS. This difference is probably due to the fact that these studies were prospective and randomized and our results are based only on patient-supplied information and reflect reallife conditions, in that our patients may have provided incorrect information on use of stockings, may not have had the financial wherewithal to purchase CS or may have abandoned CS use due to intolerance.

The detection of significant venous reflux on duplex scans may be a predisposing factor to PTS emergence. ${ }^{44}$ However, although there was a higher frequency of deep venous reflux in the TG in the present study, there was no difference in PTS frequency between the two groups.

Limitations to this study include the fact that it is retrospective and the small number of patients in each of the comparison groups. However, this is the first study with a long follow-up period that has evaluated DVT patients in developing countries, and our results show the need for a prospective multicenter study involving a greater number of patients to verify the results, since they differ from other publications.

In conclusion, after comparison of thrombophilic with non-thrombophilic patients who had been treated at our hospital for DVT of the limbs with anticoagulation and CS prescriptions, we found no differences in risk factors or other variables between the two groups, although non-thrombophilic patients had a higher incidence of rethrombosis and PE, probably because the thrombophilic patients were on anticoagulation for extended periods. The frequency of late-developing PTS was high and similar for both groups; although more of the thrombophilic patients had deep vein reflux on duplex scans.

\section{ACKNOWLEDGMENTS}

We are grateful to Dr. Rendrik França Franco for his help testing for genetic thrombophilias in some patients who also participated in a previous study.

\section{REFERENCES}

1. Maffei FHA, Rollo HA. Trombose venosa profunda dos membros inferiores: incidência, patologia, fisiopatologia e diagnóstico. In: Maffei FHA, Lastoria S, Yoshida WB, Rollo HA, editors. Doenças vasculares periféricas. 3. ed. Rio de Janeiro: Medsi; 2002. p. 1363-86

2. Castro Silva M. Venous thromboembolism in the State of Minas Gerais and its projection to Brazil: Study based in 2,331,353 hospitalizations. Intern Angiol. 1997;16:193-6.

3. McLafferty RB, Lohr JM, Caprini JA, et al. Results of the nationa pilot screening program for venous disease by the American Venous Forum. J Vasc Surg. 2007;45:142-8. http://dx.doi. org/10.1016/j.jvs.2006.08.079

4. Geerts WH, Bergqvist D, Pineo GF, et al. Prevention of Venous Thromboembolism. Chest. 2008;133:381S-453S. http://dx.doi org/10.1378/chest.08-0656

5. Rosendaal FR. Venous thrombosis: a multicausal disease Lancet. 1999;353(9159):1167-73. http://dx.doi.org/10.1016/ S0140-6736(98)10266-0

6. Franco RF, Reitsma PH. Genetic risk factors of venous thrombosis Hum Genet. 2001;109:369-84. http://dx.doi.org/10.1007/ s004390100593

7. Pomp ER, Cessie S, Rosendaal FR, Doggen CJM. Risk of venous thrombosis: obesity and its joint effect with oral contraceptive use and prothrombotic mutations. Br J Haematol. 2007;139:289-96. http://dx.doi.org/10.1111/j.1365-2141.2007.06780.x

8. D'Angelo A, Selhub J. Homocysteine and thrombotic disease. Blood. 1997;90:1-11.

9. Blom JW, Doggen CJM, Osanto S, Rosendaal FR. Malignancies, prothrombotic mutations and the risk of venous thrombosis. JAMA. 2005;293:715-22. http://dx.doi.org/10.1001/jama.293.6.715

10. Bank I, Middeldorp S, Büller HR. Hereditary and acquired thrombophilia. Semin Respir Crit Care Med. 2000;21:483-91. http://dx.doi.org/10.1055/s-2000-13190

11. Seligsohn U, Lubetsky A. Genetic susceptibility to venous thrombosis. N Engl J Med. 2001;344:1222-9. http://dx.doi. org/10.1056/NEJM200104193441607

12. Dahlbäck $B$. Resistance to activated protein $C$ caused by the $R$ $506 \mathrm{Q}$ mutation in the gene for factor $\mathrm{V}$ is a common risk factor for venous thrombosis. J Intern Med Suppl. 1997;242(740):1-8.

13. Pieroni F, Lourenço DM, Morelli VM, Maffei FH, Zago MA, Franco RF. Cytokine gene variants and venous thrombotic risk in the BRATROS (Brazilian Thrombosis Study). Thromb 
Res. 2007;120(2):221-9. http://dx.doi.org/10.1016/j. thromres.2006.09.015

14. Poort SR, Rosendaal FR, Reitsma PH, Bertina RM. A common genetic variation in the $3^{\prime}$-Untranslated region of prothrombin gene is associated with elevated plasma prothrombin levels and an increase in venous thrombosis. Blood. 1996;88:3698-703.

15. Morelli V, Lourenço DM, D'Almeida V, et al. Hyperhomocysteinemia increases the risk of venous thrombosis independent of the C677T mutation of the methylenetetrahydrofolate reductase gene in selected Brazilian patients. Blood Coagul Fibrinolysis. 2002;13:2715. http://dx.doi.org/10.1097/00001721-200204000-00014

16. Pereira AC, Lourenço D, Maffei FH, et al. A transcobalamin gene polymorphism and the risk of venous thrombosis. The BRATROS (Brazilian Thrombosis Study). Thromb Res. 2007;119:183-8. http:// dx.doi.org/10.1016/j.thromres.2006.01.008

17. Graves M. Antiphosfolipid antibodies and thrombosis. Lancet. 1999;353:1348-53 http://dx.doi.org/10.1016/ S0140-6736(98)10362-8

18. Genoud V, Castañon M, Annichino-Bizzacchi J, Korin J, Kordich $L$. Prevalence of three prothrombotic polymorphisms: fator V G1691A, fator II G20210A and methylenetetrahydrofolate reductase (MTHFR) C677T in Argentina. Thromb Res. 2000;100:12731. http://dx.doi.org/10.1016/S0049-3848(00)00314-5

19. Vossen C, Walker I, Svensson P, et al. Recurrence rate after venous thrombosis in patients with familial thrombophilia. J Vasc Biol. 2005;25:1992-97. http://dx.doi.org/10.1161/01. ATV.0000174806.76629.7b

20. Prandoni P, Kahn SR. Post-thrombotic syndrome: prevalence, prognostication and need for progress. Br J Haematol. 2009 May;145(3):286-95. http://dx.doi. org/10.1111/j.1365-2141.2009.07601.x

21. Kearon C, Kahn SR, Agnelli G, Goldhaber S, Raskob GE, Comerota AJ. Antithrombotic therapy for venous thromboembolic disease. Chest. 2008;133:454S-545S. http://dx.doi.org/10.1378/ chest.08-0658

22. Spiezia L, Campello E, Giolo E, Villalta S, Prandoni P. Thrombophilia and the risk of post-thrombotic syndrome: retrospective cohort observation. J ThrombHaemost. 2010;8:211-3. http://dx.doi. org/10.1111/j.1538-7836.2009.03655.x

23. Labropoulos N, Tiongson J, Pryior L, et al. Definition of venous reflux in lower-extremity veins. J Vasc Surg. 2003;38:793-8. http:// dx.doi.org/10.1016/S0741-5214(03)00424-5

24. Wilson W, Guaravi AE, Koike T, et al. International consensus statement on preliminary classification criteria for definite antiphospholipid syndrome: report of an International Workshop. Arthritis Rheum. 1999;42:1309-11. http://dx.doi.org/10.1002/15290131(199907)42:7<1309::AID-ANR1>3.0.CO;2-F

25. Goodman LA. Simultaneous confidence intervals for contrasts among multinomial populations. Ann Math Stat. 1964;35:716-25. http://dx.doi.org/10.1214/aoms/1177703569

26. Goodman LA. On simultaneous confidence intervals for multinomial proportions. Technometrics. 1965;7:247-54. http:// dx.doi.org/10.1080/00401706.1965.10490252

27. Zar JH. Bioestatistical analysis. 4th ed. New Jersey: Prentice Hall; 1999.

28. Norman GR, Streiner DL. Bioestatistics - the bare essentials. St Louis: Mosby Year Book; 1994.

29. Brower JL, Veeger NJGM, Kluin-Nelemans HC, Van der Meer J. The pathogenesis of venous thromboembolism: evidence for multiple interrelated causes. Ann Intern Med. 2006;145:807-15. http://dx.doi.org/10.7326/0003-4819-145-11-200612050-00005

30. Christiansen SC, Cannegieter SC, Koster T, Vandenbroucke JP, Rosendaal FR. Thrombophilia, clinical factors and recurrent venous thrombotic events. JAMA. 2005;293:2352-61. http:// dx.doi.org/10.1001/jama.293.19.2352

31. Miyakis S, Lockshin MD, Atsumi T, et al. International consensus statement on an update of the classification criteria for definite antiphospholipid syndrome (APS).J Thromb. Haemost. 2006;4:295306. http://dx.doi.org/10.1111/j.1538-7836.2006.01753.x

32. Azem F, Many A, Yovel I, Amit A, Lessing JB, Kupfermine MJ. Increase rates of thrombophilia in women with repeated IVF failures. Hum Reprod. 2004;19:368-70. http://dx.doi.org/10.1093/ humrep/deh069

33. Kovalevsky G, Gracia CR, Berlin JA, Sammel MD, Barnhart KT. Evaluation of the association between hereditary thrombophilias and recurrent pregnancy loss. Arch Intern Med. 2004;164:558-63. http://dx.doi.org/10.1001/archinte.164.5.558

34. Pabinger R, Vormittag R. Thrombophilia and pregnancy outcomes. J Throm Haemost. 2005;3:1603-10. http://dx.doi. org/10.1111/j.1538-7836.2005.01417.x

35. Souza SS, Ferriani RA, Pontes AG, Zago MA, Franco RF. Factor V Leiden and factor II G20210A mutations in patients with recurrent abortion. Hum Reprod. 1999;14:2448. http://dx.doi.org/10.1093/ humrep/14.10.2448

36. Rai R. Obstetrical management of antiphospholipid syndrome. J Autoinmun 2000;15:203-7. http://dx.doi.org/10.1006/ jaut.2000.0417

37. Lijfering WM, Brower JLP, Veeger NJGM, et al. Selective testing for thrombophilia in patients with first venous thrombosis: results from a retrospective family cohort study on absolute thrombotic risk for currently known thrombophilic defects in 2479 relatives. Blood. 2009;113:5314-22. http://dx.doi.org/10.1182/ blood-2008-10-184879

38. Tosetto A, Rodeghiero F, Martinelli I, et al. Additional genetic risk factors for venous thromboembolism in carriers of the factor $\mathrm{V}$ Leiden mutation. Br J Haematol. 1998;103:8-50. http://dx.doi. org/10.1046/j.1365-2141.1998.01028.x

39. Martinelli I, Battaglioni T, Razzari C, Mannucci M. Type and location of venous thromboembolism in patients with factor $\checkmark$ Leiden or prothrombin G20210A and in those with no thrombophilia. J Throm Haemost. 2007;5:98-101. http://dx.doi. org/10.1111/j.1538-7836.2006.02291.x

40. Prandoni P, Lensing AWA, Cogo $A$, et al. The long-term clinical course of deep venous thrombosis. Ann Intern Med. 1996;125:1-7. http://dx.doi.org/10.7326/0003-4819-125-1-199607010-00001

41. Brandjes DP, Baller HR, Heijboer $\mathrm{H}$, et al. Randomised trial of effect of compression stocking in patients with symptomatic proxinal-vein thrombosis. Lancet. 1997;349:759-62. http://dx.doi. org/10.1016/S0140-6736(96)12215-7

42. Kahn SR, Solymoss S, Lamping DL, Abenhaim L. Long-term outcomes after deep vein thrombosis: postphlebitic syndrome and quality of life. J Gen Intern Med. 2000;15:425-9. http://dx.doi. org/10.1046/j.1525-1497.2000.06419.x

43. Kahn SR, Kearon C, Julian JA, et al. Predictors of the postthrombotic syndrome during long-term treatment of proximal deep vein thrombosis. J Thromb Haemost. 2005;3:718-23.

44. Pesavento R, Bernardi E, Concolato A, Dalla Vale F, Pagnan A, Prandoni P. Posstthrombotic syndrome. Semin Thromb Hemost. 2006;32:744-751. http://dx.doi.org/10.1055/s-2006-951460 
Correspondence Viviane Alessandra Capelluppi Tófano Rua Paula Fabiana Tudela, 116 - Esmeralda CEP 17516-707 - Marília (SP), Brazil Fone: +55 (14) 2105-4536 Fax: +55 (14) 34543815 E-mail:vic.@uol.com.br; rtofano@uol.com.br

Author information VACT. MD, PhD, Professor of the Medical School at the Universidade de Marilia (Unimar) and Teaching Assistant at Faculdade de Medicina de Marília (FAMEMA)

FHAM. MD, PhD, Emeritus Professor at Faculdade de Medicina de Botucatu, Universidade Estadual Paulista (UNESP).

HAR. MD, PhD, Associate Professor of the Department of Surgery and Orthpedics, Faculdade de Medicina de Botucatu, Universidade Estadual Paulista (UNESP).

MLS. MD, PhD, Assistant Professor, Department of Surgery and

Orthpedics, Faculdade de Medicina de Botucatu, Universidade Estadual Paulista (UNESP).

CRP. Professor at the Department of Bioestatistics at the Instituto de

Biociencias, Universidade Estadual Paulista (UNESP).

ITAS. PhD, Biologist, Head of the Hemostasis Laboratory, Blood Center at Faculdade de Medicina de Botucatu, Universidade Estadual Paulista (UNESP).

Author contributions Conception and design: VACT, FHAM Analysis and interpretation: VACT Data collection: VACT Writing the article: VACT

Critical revision of the article: FHAM Final approval of the article: VACT, FHAM, HAR, MLS, CRP, ITAS Statistical analysis: CRP Ultrasonographic analysis: HAR, MLS

Laboratory exams analysis: ITAS Overall responsibility: VACT Obtained funding: None

*All authors have read and approved of the final version of the article submitted to J Vasc Bras. 